\title{
Introduction to the special issue "The Valley of Lakes in Mongolia, a key area of Cenozoic mammal evolution and stratigraphy"
}

\author{
Gudrun Daxner-Höck $^{1,2}$ • Ursula B. Göhlich ${ }^{1}$
}

Received: 16 December 2016 / Accepted: 20 December 2016/Published online: 21 January 2017

(C) Senckenberg Gesellschaft für Naturforschung and Springer-Verlag Berlin Heidelberg 2017

Located at the eastern end of the Central Asian Plateau between China and Russia, Mongolia is a mountainous country with glaciers on the highest peaks and forests covering the northern and central part. From north to south, Mongolia passes through several habitat zones, from forested landscapes along the northern border to steppe and semi-desert in the middle part, to wide grasslands of the great eastern steppe, and finally to Gobi desert along its entire southern part. Mongolia covers an area of $1,566,500 \mathrm{~km}^{2}$, which is roughly the size of Western Europe. It is a plateau landscape with an average elevation of $1580 \mathrm{~m}$, and mountain ranges exceeding $4000 \mathrm{~m}$ elevation. Our working area, the Taatsiin Gol- and Taatsiin Tsagaan Nuur region, ranging from $100^{\circ} 55^{\prime}$ to $102^{\circ}$ $05^{\prime}$ longitude and $45^{\circ} 11^{\prime}$ to $45^{\circ} 45^{\prime}$ latitude, is part of the Valley of Lakes, which itself is an intermountain depression with a NW-SE longitudinal axis. It is bounded by the Khangai Mountains in the north and the Gobi Altai Mountains in the south (Fig. 1).

The initial geological research and discoveries of rich fossil beds made during the Central Asiatic Expeditions by the American Museum of Natural History in the 1920s was followed by comprehensive geologic and palaeontological research in the frame of several joint expeditions. These include the Soviet-Mongolian Geological and Paleontological

This article is a contribution to the special issue "The Valley of Lakes in Mongolia, a key area of Cenozoic mammal evolution and stratigraphy"

Ursula B. Göhlich

ursula.goehlich@nhm-wien.ac.at

Gudrun Daxner-Höck

gudrun.hoeck@nhm-wien.ac.at; gudrun.hoeck@sbg.at

1 Natural History Museum Vienna, Burgring 7, 1010 Vienna, Austria

2 Rupertusstraße 16, 5201 Seekirchen, Austria
Expeditions, the Polish-Mongolian Paleontological Expedition and finally the Mongolian-American joint expeditions of the Mongolian Academy of Sciences and the American Museum of Natural History, in the 1990s.

After participating in the International Geoscience Programme (IGCP, Project 326) in 1993, which focused on the Oligocene-Miocene Transition in the Northern Hemisphere, one of us (GDH) started a new Mongolian-Austrian project in the Taatsiin Gol and Taatsiin Tsagaan Nuur region. The geology of these regions was rather unstudied at that time, but the interlocking of deposits rich in vertebrate fossils and several datable basalts were promising preconditions for interdisciplinary geological and palaeontological investigations. Throughout the past 20 years, three major projects with differing programs of emphasis and scientific objectives have been conducted. For all these projects, which were all exclusively granted by the Austrian Science Fund (FWF-projects: P-10505-GEO, P15724-N06 and P-23061-N19), G. Daxner-Höck (Natural History Museum Vienna) was the project leader and coordinator. In collaboration with the Mongolian Academy of Sciences and the Natural History Museum of Vienna, fieldwork was carried out during eight field seasons (1995-1997, 2001, 2004, 2006 and 2011-2012).

The Oligocene to Miocene sediment sequences of the Taatsiin Gol and Taatsiin Tsagaan Nuur region, long known for their fossil richness and basaltic volcanism, allowed a stratigraphic adjustment based on the evolution of mammals and on age datings of the basalts (Höck et al. 1999). Our comprehensive geological investigations included geological mapping, lithological studies, sedimentology and tectonics, ${ }^{40} \mathrm{Ar} /{ }^{39} \mathrm{Ar}$-dating of basalts, magnetic susceptibility and gamma log measurements and geochemical analyses for determination of $\delta^{18} \mathrm{O}$ and $\delta^{13} \mathrm{C}$ patterns of sediments. Along numerous sections and fossil sites, between the regions of Menkhen Teeg in the west and Ikh Argalatyn Nuruu in the east, 
Fig. 1 The grey rectangle marks the working area in the Valley of Lakes, Mongolia

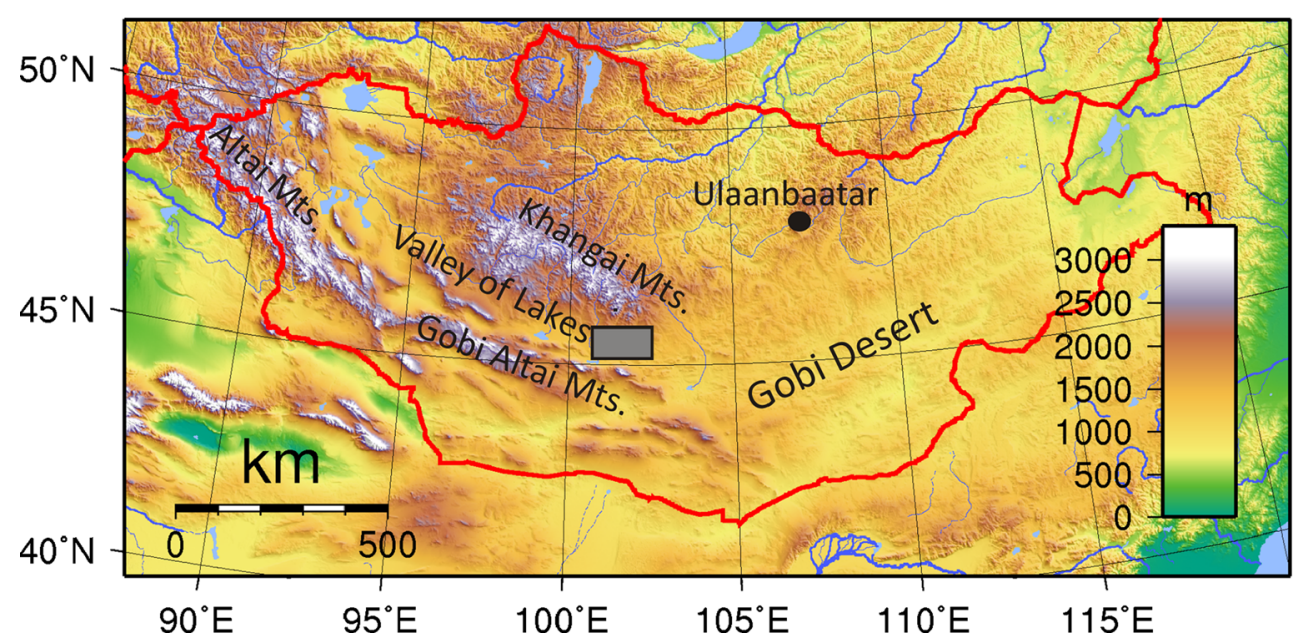

extremely rich vertebrate assemblages were collected by bedby-bed sampling and wet screening (Fig. 2). This method of collecting small mammal fossils was introduced by one of us $(\mathrm{GDH})$ in Mongolia for the first time in 1995. Since then, more than $80 \mathrm{t}$ of stratified samples have been screen washed within these projects, resulting in an outstanding collection of about 19,000 determinable fossil specimens dominated by small mammals. The gained fossils are housed in parts in the Natural History Museum of Vienna and in the Paleontological Institute of the Mongolian Academy of Sciences in Ulaanbataar. 175 fossil mammalian species were identified in the investigated sections, 32 of which were newly described species. They are complemented by nine herpetological and ten gastropod taxa. A complete faunal list is given in Daxner-Höck et al. (2017, this issue, tab. 18). The fieldwork was carried out by changing teams of Mongolian and European members. This work in Mongolia led to important results and subsequent publications, including an integrated stratigraphy based on Oligocene-Miocene sediment, basalt and fossil associations (Daxner-Höck et al. 1997, 2010; Höck et al. 1999), a reconstruction of climatic changes (Harzhauser et al. 2016) and taxonomic studies performed on different fossil groups: Gastropoda (Stworzewicz 2007; Neubauer et al. 2013), lower vertebrates (Böhme 2007), small mammals (Daxner-Höck 2000, 2001; Daxner-Höck and Wu 2003; Erbajeva 2007, 2013; Schmidt-Kittler et al. 2007; Ziegler et al. 2007; Erbajeva and Daxner-Höck 2014; Wessels et al. 2014; Daxner-Höck et al. 2013, 2014, 2015; Maridet et al. 2014a, b, 2015) and large mammals (Vislobokova and DaxnerHöck 2002; Morlo and Nagel 2002, 2006, 2007; Nagel and Morlo 2003; Göhlich 2007; Heissig 2007). The enamel microstructure of Paleogene and early Neogene rodent teeth from Mongolia was analysed by Koenigswald and Kalthoff (2007). Both, the fieldwork and the resulting publications, were performed by an international team of researchers from 15 countries (from Mongolia, Russia, China, Germany, the Netherlands, Italy, Switzerland, France, Sweden, Spain, Czech Republic, Poland, USA, Bolivia and Austria). The integrated stratigraphy was completed by magnetostratigraphic investigations (Kraatz and Geisler 2010; Sun and Windley 2015).

The manifold fieldwork within the Mongolian-Austrian projects during the past 20 years was not only supported by collaborating Mongolian colleagues but also by local nomadic helpers and local drivers. Besides scientific collaborations, also some ties of friendship arose with some colleagues and long-term local nomadic helpers. During all field seasons of the past 20 years, Demchig Badamgarav $\dagger$ acted as geological guide and translator, cared for administrative tasks and became a partner and friend. The same is true for the nomad families Ch. Tomurbaatar and L. Olzibaatar, who assisted actively in all field seasons in collecting and wet screening of samples and selecting fossils from washed residual (Fig. 3). But they also assisted in caring for the research yurt camp and provided locally produced food (e.g. milk products, or a slaughtered goat or sheep) for the expedition team (Figs. 4 and 5). The warm and close tie between G. DaxnerHöck and all the members of these two nomadic families was expressed by the latter by naming her "edsch" or "undr edsch" (mother or caring mother). Also a permanent member of the expedition Mongolian-Austrian team was the local driver Radna, who discretely drove G. Daxner-Höck and her team cross-country through Mongolia for 20 years.

The special issue in hand presents the multidisciplinary results of the most recent project entitled "Impact of OligoMiocene climate changes on Mongolian mammals" (FWF P-23061-N19) carried out in the Valley of Lakes, including geology and geochemistry, mammal taxonomy and evolution, stratigraphy and correlations, throughout the Oligocene and across the Eocene/Oligocene and Oligocene/Miocene transitions. Fossil collections deriving from older expeditions, and faunas younger than earliest Miocene, are not considered in these contributions.

This special issue presents the following contributions:

Erbajeva et al. 2017 present the Ochotonidae genus Sinolagomys, its occurrences in the late Oligocene and early 

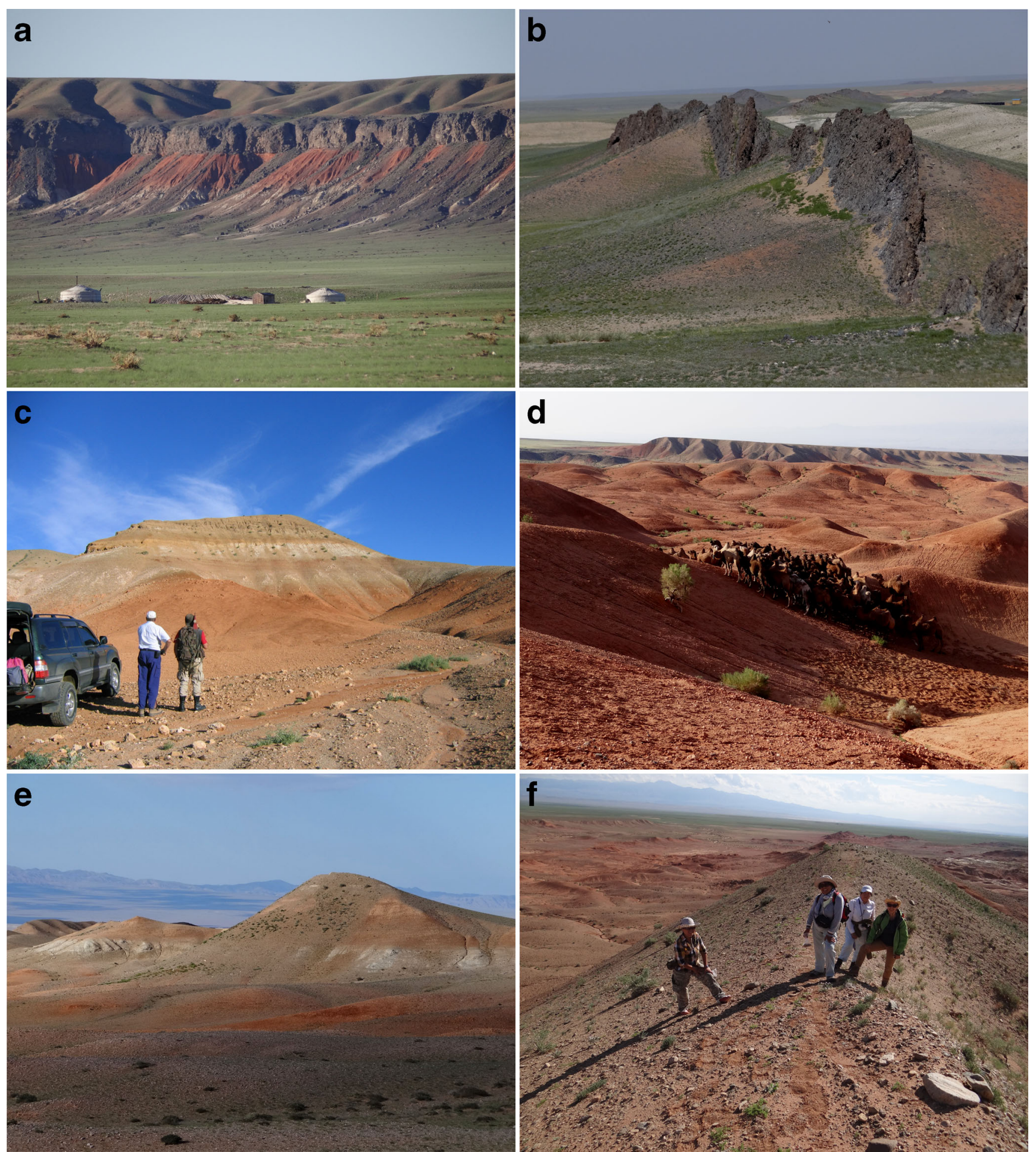

Fig. 2 Sections and fossil localities of the Taatsiin Gol and Taatsiin Tsagaan Nuur region. a Locality Taatsiin Gol at the orographic right side of river Taatsiin. From base to top, the sediment sequences comprises the Tsagan Ovo Formation, the red clay and basalt I (31.5 Ma) of the Hsanda Gol Formation and on top the sequences of the Loh- and Tuyn Gol Formations. b Locality Del. Along of the Delfault basalt I is tilted towards south. The white-grey sands of the Tsagan Ovo Formation (at the right side of the picture) are followed by the red

coloured lower Hsanda Gol beds and basalt I in almost vertical position. Left side (south) of basalt I the upper Hsanda Gol beds are exposed. c Locality Taatsiin Gol south, section TGR-C. d Locality Tatal Gol with view towards SE. In front, the red clay of the upper Hsanda Gol beds. e Locality Loh, section LOH-B. The sediment sequence ranges from the late Oligocene to the Miocene. f Locality Hsanda Gol displays the red clay- and caliche sequences of the Hsanda Gol Formation (upper Hsanda Gol beds) 

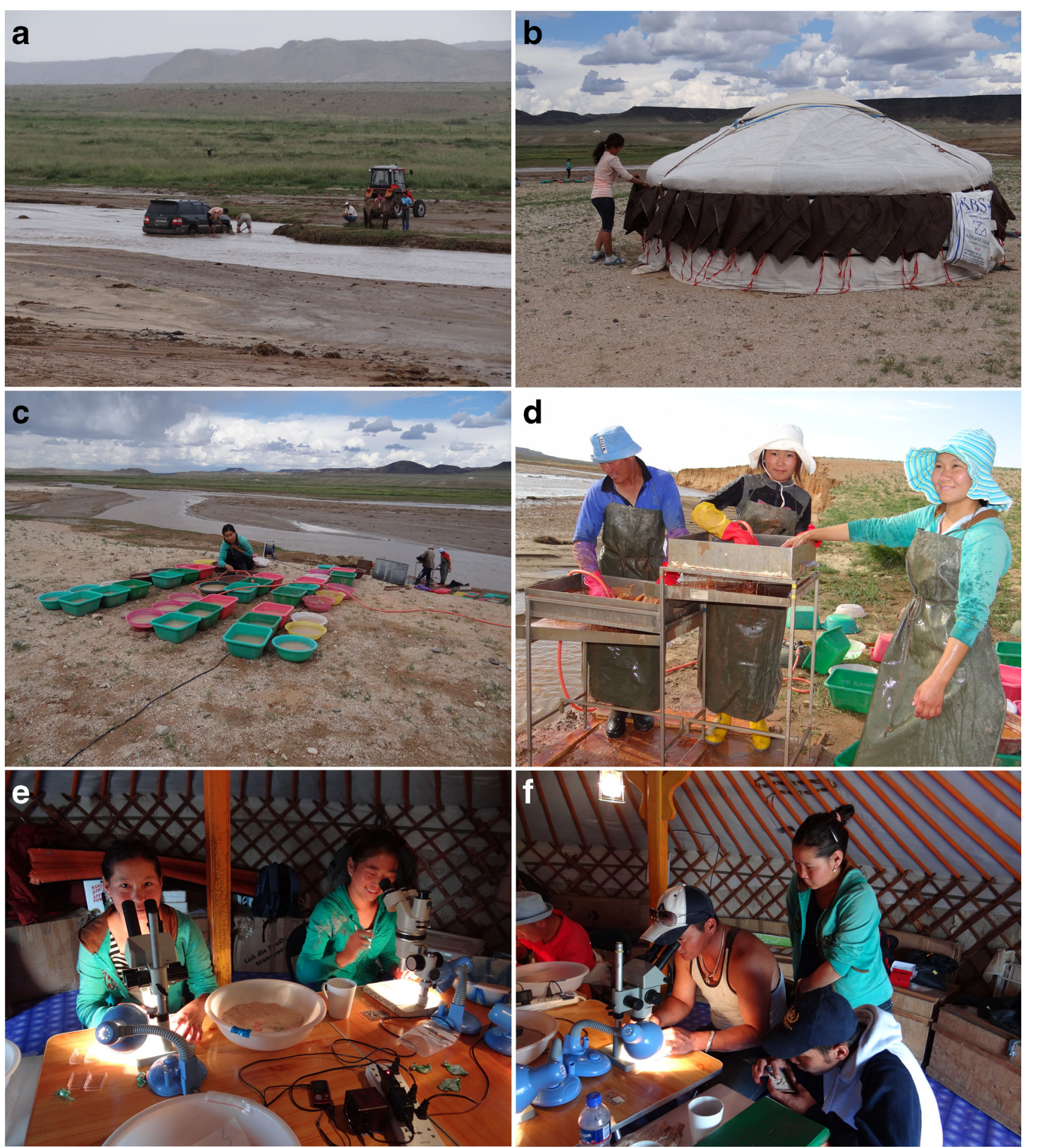

Fig. 3 Field laboratory and camp at the Taatsiin river. a Sample transport across the flooded river is a challenge for our cross-country car. b The cleaned sample bags dry outside of the nomad tent. c-d Soaking and wet

Miocene of Mongolia, China and Kazakhstan. Five Sinolagomys species are evidenced from thirty fossil layers of the Valley of Lakes; one of them the new species

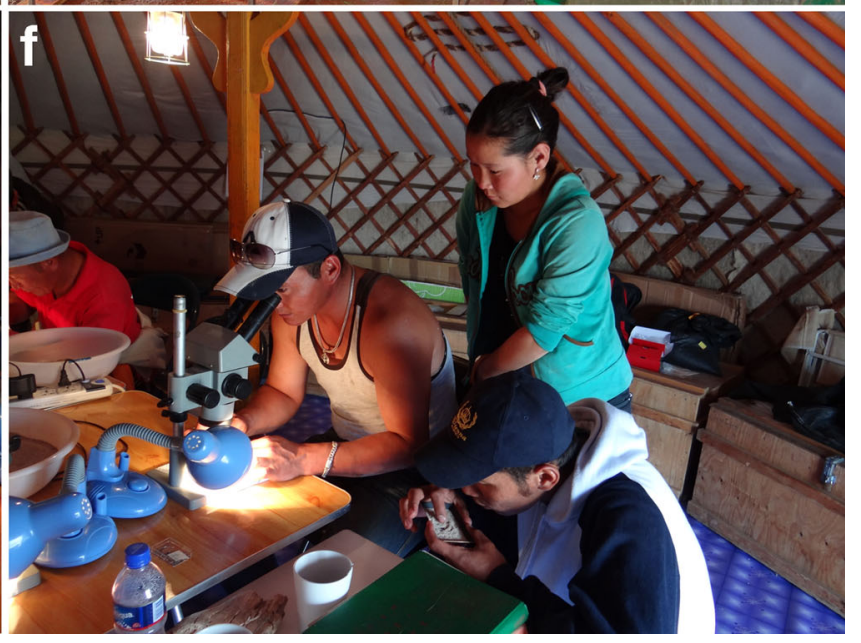

screening of palaeontological samples. e-f After screening, fossils were selected from the residual by members of the assisting nomad families using Russian field binoculars
Sinolagomys badamae sp. nov. discovered from the Tatal Gol and Toglorhoi localities (Palaeobiodiversity and Palaeoenvironments 97(1) Doi: 10.1007/s12549-016-0262-z). 

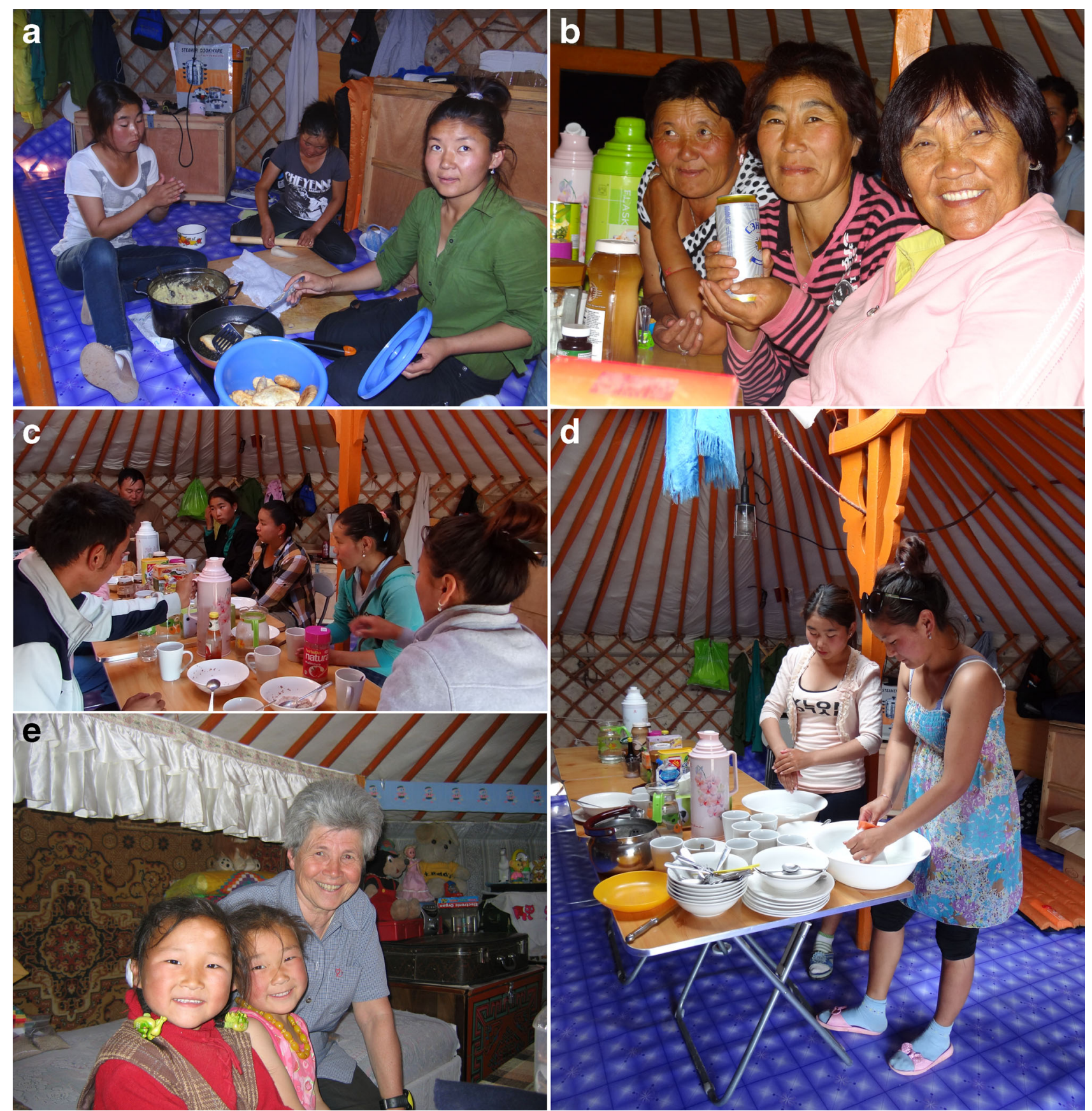

Fig. 4 Social life with some members of our long-term assisting nomad families in the nomad tent, Mongolian term "ger". a, d Nomad girls prepare Mongolian food for dinner and take care of the "field kitchen". b D. Badamgarav (right side) accompanied by two nomad ladies, who

provide meat, milk and yoghurt for our meals. $\mathbf{c}$ Breakfast in the Taatsiin camp. e G. Daxner-Höck and two nomad children from the Taatsiin region

in Asia (Palaeobiodiversity and Palaeoenvironments 97(1) Doi: 10.1007/s12549-016-0225-y).

and early Miocene Aplodontidae from the Taatsiin Gol and Taatsiin Tsagaan Nuur region and describe the dental morphology, mandibles and a skull. Comprising seven species out of five genera (Ninamys, Prosciurus, Promeniscomys, Proansomys and Ansomys), at present, the record of Aplodontidae from Mongolia is higher than from adjacent areas

Oliver et al. 2017 review the rodent family Ctenodactylidae occurring in Oligocene deposits of the Valley of Lakes, and report about two new Prodistylomys species in the early Miocene. The contribution provides systematics as well as 


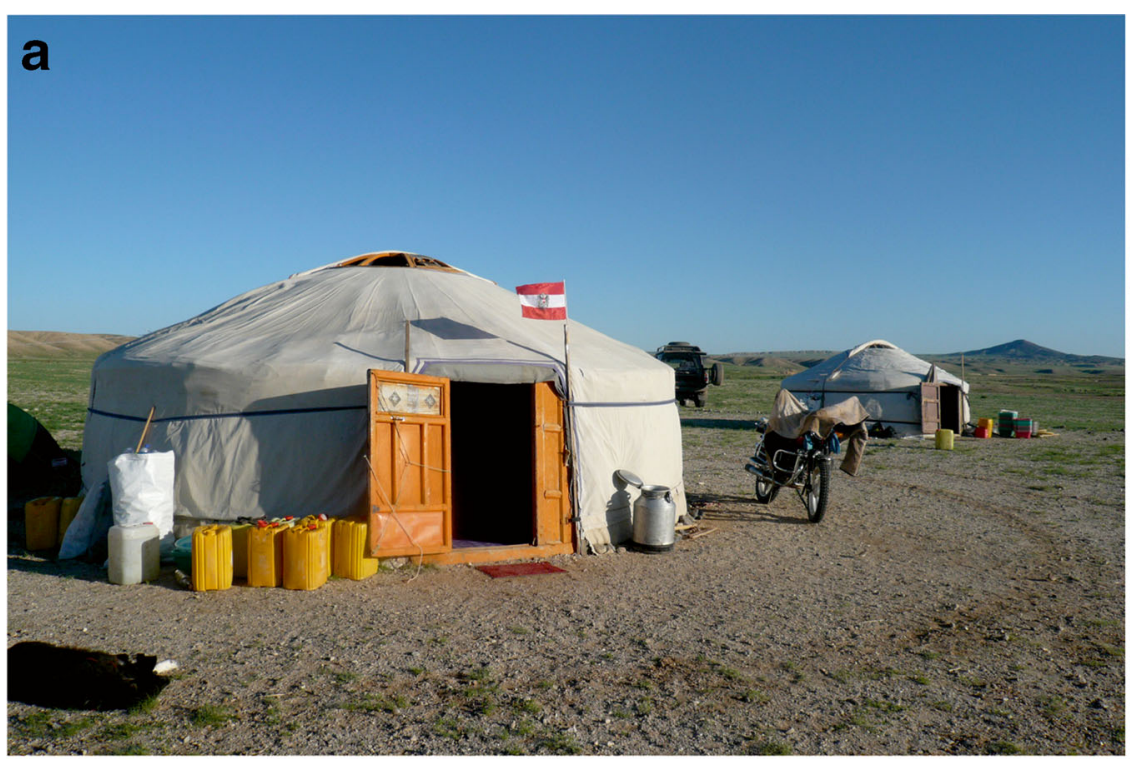

b
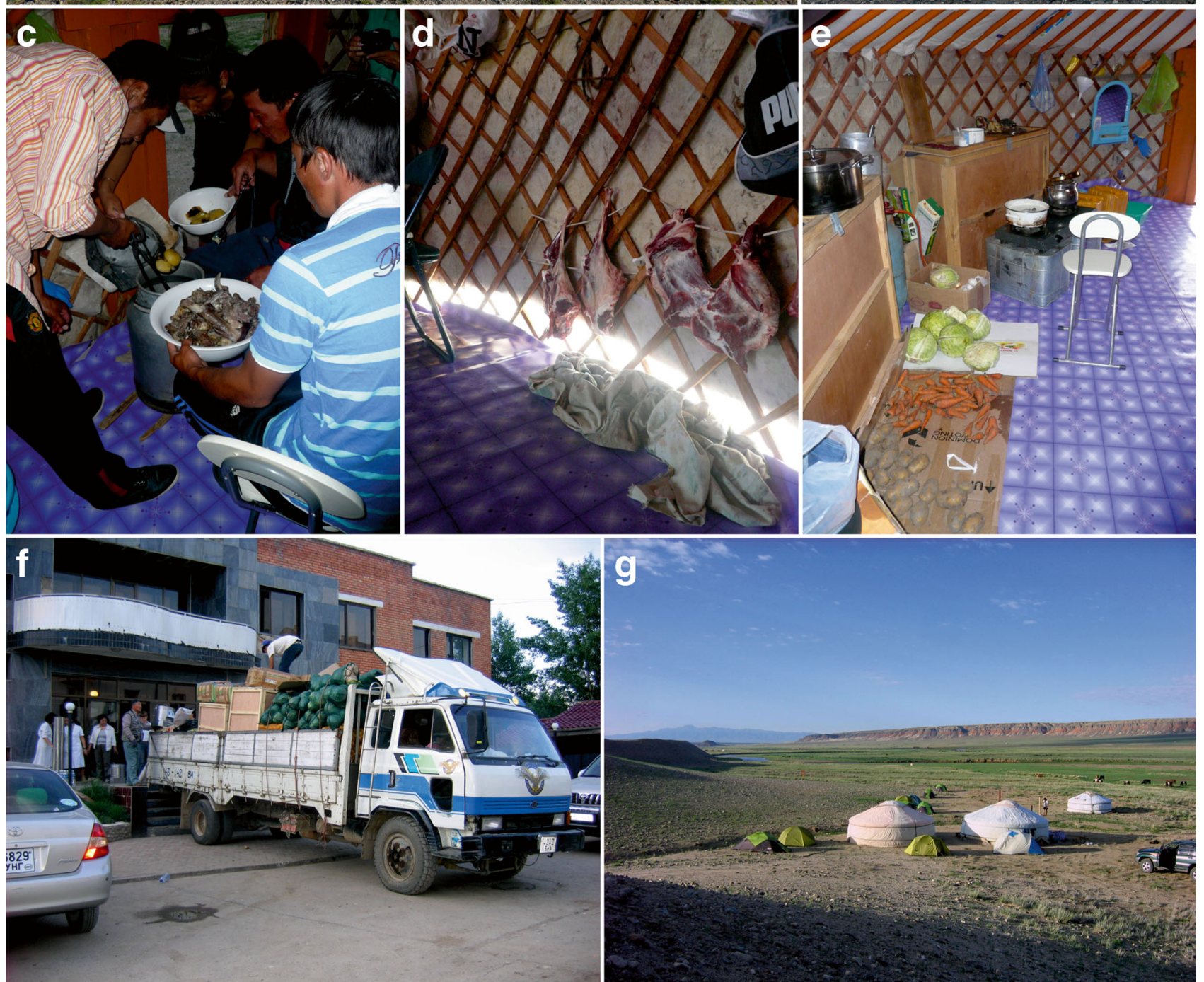

Fig. 5 a "Field kitchen yurt" of the Austrian-Mongolian research camp with the Austrian flag. b Project leader Gudrun Daxner-Höck. c Traditional Mongolian dish, fried goat. $\mathbf{d}$ freshly slaughtered sheep meat fixed at the wall of "field kitchen yurt" for drying. e Food and equipment

in field kitchen. f Charging truck in Ulaanbaatar with equipment and food (e.g. white cabbage) for field camp. g Research camp in the Taatsiin Gol Valley with "working yurt", "field kitchen yurt" and smaller "shower yurt" and sleeping tents for the expedition members 
stratigraphic ranges and regional distributions of the represented Ctenodactylidae, and assumes relations with climate changes. It can be shown that the early- and beginning late Oligocene Ctenodactylidae associations (Karakoromys, Huangomys Tataromys and Yindirtemys) show smaller toothsizes and species richness, whereas in the period of the "Late Oligocene Warming", the increasing tooth-size of the genus Yindirtemys goes along with a dramatic drop of diversity of the family (Palaeobiodiversity and Palaeoenvironments 97(1) Doi: 10.1007/s12549-016-0265-9).

López-Guerrero et al. 2017a describe five Eucricetodon species from the Oligocene of the Valley of Lakes. Two of these species (E. caducus and E. asiaticus) were already known from the region, but E. bagus, E. jilantaiensis and E. occasionalis were hitherto unknown. The article comprises systematic descriptions, illustrations and tooth measurements of the represented taxa. A stratigraphic table presents the stratigraphic ranges of the species in terms of Mongolian biozones and the chronostratigraphic correlation of the Mongolian biozones A to C1 (Palaeobiodiversity and Palaeoenvironments 97(1) Doi: 10.1007/s12549-0160256-x).

López-Guerrero et al. 2017b present a second contribution on Cricetidae from the Valley of Lakes, dealing with the genera Aralocricetodon, Eocricetodon, Bagacricetodon, Witenia and Paracricetodon. The article provides systematics, dental measurements and SEM-illustrations, the quantitative distribution of the fossils from respective localities/fossil layers and the stratigraphic ranges and regional distributions of the studied cricetid taxa. An overview of the evolution of Cricetidae from Mongolia evidences the genera Eucricetodon, Eocricetodon, Witenia and Paracricetodon in early Oligocene fossil sites, Aralocricetodon, Argyromys and Bagacricetodon in the late Oligocene (Palaeobiodiversity and Palaeoenvironments 97(1) Doi: 10.1007/s12549-016-0266-8).

Daxner-Höck et al. 2017 provide a comprehensive and detailed compilation of the geology and stratigraphy of the Taatsiin Gol and Taatsiin Tsagaan Nuur region. It summarises all geological field data and results, which have been collected during the past 20 years of investigation within this MongolianAustrian projects. In the studied region, Cenozoic strata are intercalated with basalt flows, and ${ }^{40} \mathrm{Ar} /{ }^{39} \mathrm{Ar}$-data provide a timeframe for sediment deposition and their included fossils. Thus, basalt ages and Mongolian letter zones A, B, C, C1, C1$\mathrm{D}$ and $\mathrm{D}$ yield a composite age chronology. From the Oligocene and early Miocene part of the studied region, 20 geological sections and five fossil sites including lithological descriptions and fossil lists are given. Seventy fossil beds yielded more than 19,000 mammal fossils. This huge collection encompasses 175 mammal species: 50\% Rodentia, 13\% Eulipotyphla and
Didelphomorphia and 12\% Lagomorpha. The remaining 25\% of species are distributed among herbivorous and carnivorous large mammals. The representation of lower vertebrates and gastropods is comparatively poor. Substantial SEM image illustrations visualize the manifold dental morphology of the represented taxa of marsupials, insectivores and rodents. A table lists all investigated fossil taxa and their respective stratigraphic ranges in the studied area (Palaeobiodiversity and Palaeoenvironments 97(1) Doi: 10.1007/s12549-016-0257-9).

Harzhauser et al. 2017 test and evaluate the informal biozonation scheme that has been traditionally used for biostratigraphic correlations within the Taatsiin Gol and Taatsiin Tsagaan Nuur basins. Based on the analysis of the huge dataset of mammal fossils, a formalized biozonation is proposed according to the International Stratigraphic Guide. It results in the Cricetops dormitor Taxon Range Zone (Rupelian), subdivided into the Allosminthus khandae Taxon Range Subzone and the Huangomys frequens Abundance Subzone, the Amphechinus taatsiingolensis Abundance Zone (early Chattian), the Amphechinus major Taxon Range Zone (late Chattian), subdivided into the Yindirtemys deflexus Abundance Subzone and the Upper Amphechinus major Taxon Range Zone, and the Tachyoryctoides kokonorensis Taxon Range Zone (Aquitanian). In statistical analyses, samples attributed to these biozones form distinct clusters, indicating that each biozone was also characterised by a distinct faunal type (Palaeobiodiversity and Palaeoenvironments 97(1) Doi: 10.1007/s12549-016-0264-x).

Richoz et al. 2017 present the mostly siliciclastic sediments with several levels of paleosols for their sedimentology, mineralogy, major and trace element composition and $\delta^{13} \mathrm{C}$ and $\delta^{18} \mathrm{O}$ composition. The obtained results show that temperate hydrothermal fluids induced a strong illitization of the fluvial and lacustrine sediments. The novel $\delta^{13} \mathrm{C}$ and $\delta^{18} \mathrm{O}$ record suggests an early Oligocene aridification in Central Asia at $\sim 31 \mathrm{Ma}$, whereas the Oligocene glacial maximum shows no increase in aridification. A second, regional-scale aridification occurred at $\sim 25 \mathrm{Ma}$ and corresponds to a late Oligocene marked mammalian turnover in the Valley of Lakes sediments (Palaeobiodiversity and Palaeoenvironments 97(1) Doi: 10.1007/s12549-016-0268-6).

Acknowledgements We are very grateful to our Mongolian friend and partner Demchig Badamgarav $\dagger$, she was geologist, and for almost 20 years guide, translator and collaborator of the Mongolian-Austrian research team.

Special thanks to the editors Sinje Weber and Peter Königshof for their interest in our research and for their friendly and professional management of the editorial process. We are also grateful to the Austrian Science Fund (FWF) for granting the publication costs (Open Access) for all contributions of this issue carried out in the frame of the FWF-project P-23061-N19. 


\section{References}

Böhme, M. (2007). 3. Herpetofauna (Anura, Squamata) and paleoclimatic implications: preliminary results. In G. Daxner-Höck (Ed), Oligocene-Miocene Vertebrates from the Valley of Lakes (Central Mongolia): Morphology, Phylogenetic and Stratigraphic Implications. Annalen des Naturhistorischen Museums Wien, 108A, 43-52.

Daxner-Höck, G. (2000). Ulaancricetodon badamae n. gen. n. sp. (Mammalia, Rodentia, Cricetidae) from the Valley of Lakes in Central Mongolia. Paläontologische Zeitschrift, 74(1/2), 215-225.

Daxner-Höck, G. (2001). New zapodids (Rodentia) from OligoceneMiocene deposits in Mongolia. Part 1. Senckenbergiana lethaea, 81(2), 359-389.

Daxner-Höck, G., \& Wu, W. Y. (2003). Plesiosminthus (Zapodidae, Mammalia) from China and Mongolia: migrations to Europe. In J. W. Reumer, \& W. Wessels (Eds.), Distribution and migration of Tertiary mammals in Europe. Deinsea, 10, 127-151.

Daxner-Höck, G., Höck, V., Badamgarav, D., Furtmüller, G., Frank, W., Montag, O. \& Schmid, H.P. (1997). Cenozoic stratigraphy based on a sediment-basalt association in Central Mongolia as requirement for correlation across Central Asia. In J.P. Aguilar, S. Legendre, S. \& J. Michaux (Eds.), Biochronologie mammalienne du Cénozoique en Europe et domaines reliés. Mémoires et Travaux de l'Institut de Montpellier, E.P.H.E., 21, 163-176.

Daxner-Höck, G., Badamgarav, D., \& Erbajeva, M. (2010). Oligocene stratigraphy based on a sediment-basalt association in Central Mongolia (Taatsiin Gol and Taatsiin Tsagaan Nuur Area, Valley of Lakes): review of a Mongolian-Austrian project. Vertebrata PalAsiatica, 48(4), 348-366.

Daxner-Höck, G., Badamgarav, D., Erbajeva, M., \& Göhlich, U. B. (2013). Miocene mammal biostratigraphy of Central Mongolia (Valley of Lakes). New results. In X. Wang, L. J. Flynn, \& M. Fortelius (Eds.), Fossil mammals of Asia. Neogene biostratigraphy and chronology (pp. 477-494). New York: University Press.

Daxner-Höck, G., Badamgarav, D., \& Maridet, O. (2014). Dipodidae (Rodentia, Mammalia) from the Oligocene and Early Miocene of Mongolia. Annalen des Naturhistorischen Museums Wien, 116, 131-214.

Daxner-Höck, G., Badamgarav, D., \& Maridet, O. (2015). Evolution of Tachyoryctoidinae (Rodentia, Mammalia): evidences of the Oligocene and Early Miocene of Mongolia. Annalen des Naturhistorischen Museums Wien, 117, 161-195.

Daxner-Höck, G., Badamgarav, D., Barsbold, R., Bayarmaa, B., Erbajeva, M., Göhlich, U.B., Harzhauser, M., Höck, V., Höck, E., Ichinnorov, N., Khand, Y., López-Guerrero, P., Maridet, O., Neubauer, T.A., Oliver, A., Piller, W.E., Tsogtbaatar, K., \& Ziegler, R. (2017). Oligocene stratigraphy across the Eocene and Miocene boundaries in the Valley of Lakes (Mongolia). In G. Daxner-Höck, \& U.B. Göhlich (Eds.) The Valley of Lakes in Mongolia, a key area of Cenozoic mammal evolution and stratigraphy. Palaeobiodiversity and Palaeoenvironments, 97(1) doi:10.1007/s12549-016-0257-9. (this issue).

Erbajeva, M.A. (2007). 5. Lagomorpha (Mammalia): preliminary results. In G. Daxner-Höck (Ed.), Oligocene-Miocene vertebrates from the Valley of Lakes (Central Mongolia): morphology, phylogenetic and stratigraphic implications. Annalen des Naturhistorischen Museums in Wien, 108A, 165-171.

Erbajeva, M. A. (2013). New species of Amphilagus (Lagomorpha, Mammalia) from the Miocene of the Valley of Lakes, Central Mongolia. Paleontological Journal, 47(3), 311-320.

Erbajeva, M. A., \& Daxner-Höck, G. (2014). The most prominent Lagomorpha from the Oligocene and Early Miocene of Mongolia. Annalen des Naturhistorischen Museums Wien, 116, 215-245.

Erbajeva, M.A., Bayarmaa, B., Daxner-Höck, G., \& Flynn, L.J. (2017). The occurrence of Sinolagomys (Lagomorpha) from the Valley of
Lakes (Mongolia). In G. Daxner-Höck, \& U.B. Göhlich (Eds.) The Valley of Lakes in Mongolia, a key area of Cenozoic mammal evolution and stratigraphy. Palaeobiodiversity and Palaeoenvironments, 97(1). doi:10.1007/s12549-016-0262-z (this issue).

Göhlich, U.B. (2007). 9. Gomphotheres (Proboscidea, Mammalia) from the Early-Middle Miocene of Central Mongolia. In G. Daxner-Höck (Ed.) Oligocene-Miocene Vertebrates from the Valley of Lakes (Central Mongolia): Morphology, phylogenetic and stratigraphic implications. Annalen des Naturhistorischen Museums Wien, 108A, 271-289.

Harzhauser, M., Daxner-Höck, G., López-Guerrero, P., Maridet, O., Oliver, A., Piller, W. E., Richoz, S., Erbajeva, M. A., Neubauer, T. A., \& Göhlich, U. B. (2016). Stepwise onset of the Icehouse world and its impact on Oligo-Miocene Central Asian mammals. Scientific Reports, 6, 36169. doi:10.1038/srep36169.

Harzhauser, M., Daxner-Höck, G., López-Guerrero, P., Maridet, O., Oliver, A., Piller, W.E., Richoz, S., Erbajeva, M.A., \& Göhlich, U.B. (2017). Oligocene and early Miocene biostratigraphy of the Valley of Lakes in Mongolia. In G. Daxner-Höck and U.B. Göhlich (Eds.) The Valley of Lakes in Mongolia, a key area of Cenozoic mammal evolution and stratigraphy. Palaeobiodiversity and Palaeoenvironments, 97(1). doi:10.1007/s12549-016-0264-x (this issue).

Heissig, K. (2007). 8. Rhinocerotidae (Perissodactyla, Mammalia). In G. Daxner-Höck (Ed.), Oligocene-Miocene vertebrates from the Valley of Lakes (Central Mongolia): morphology, phylogenetic and stratigraphic implications. Annalen des Naturhistorischen Museums in Wien, 108A, 233-269.

Höck, V., Daxner-Höck, G., Schmid, H. P., Badamgarav, D., Frank, W., Furtmüller, G., Montag, O., Barsbold, R., Khand, Y., \& Sodov, J. (1999). Oligocene-Miocene sediments, fossils and basalts from the Valley of Lakes (Central Mongolia) - an integrated study. Mitteilungen der Geologischen Gesellschaft, 90, 83-125.

Koenigswald, W.v., \& Kalthoff, D. (2007). 10. The enamel microstructure of molars and incisors of Paleogene and early Neogene rodents from Mongolia. In G. Daxner-Höck (Ed.) Oligocene-Miocene vertebrates from the Valley of Lakes (Central Mongolia): morphology, phylogenetic and stratigraphic implications. Annalen des Naturhistorischen Museums in Wien, 108A, 291-312.

Kraatz, P., \& Geisler, J. H. (2010). Eocene-Oligocene transition in Central Asia and its effects on mammalian evolution. Geology, 38(2), 111114. doi:10.1130/G30619.1.

López-Guerrero, P., Maridet, O., \& Daxner-Höck, G. (2017a). Evolution of the genus Eucricetodon (Rodentia, Mammalia) from the Valley of Lakes (Mongolia): a taxonomical description and update on the stratigraphical distribution. In G. Daxner-Höck, \& U.B. Göhlich (Eds.) The Valley of Lakes in Mongolia, a key area of Cenozoic mammal evolution and stratigraphy. Palaeobiodiversity and Palaeoenvironments, 97(1). doi:10.1007/s12549-016-0256-x.

López-Guerrero, P., Maridet, O., \& Daxner-Höck, G. (2017b). The Cricetidae (Rodentia, Mammalia) from the Oligocene of the Valley of Lakes (Mongolia): the genera Aralocricetodon and Eocricetodon, Bagacricetodon, Witenia and Paracricetodon. In G. Daxner-Höck, \& U.B. Göhlich (Eds.) The Valley of Lakes in Mongolia, a key area of Cenozoic mammal evolution and stratigraphy. Palaeobiodiversity and Palaeoenvironments, 97(1). doi:10.1007/s12549-016-0266-8.

Maridet, O., Daxner-Höck, G., Badamgarav, D., \& Göhlich, U. B. (2014a). New discoveries of Sciurids (Rodentia, Mammalia) from the Valley of Lakes (Central Mongolia). Annalen des Naturhistorischen Museums Wien, 116, 271-291.

Maridet, O., Daxner-Höck, G., Badamgarav, D., \& Göhlich, U. B. (2014b). Cricetidae (Rodentia, Mammalia) from the Valley of Lakes (Central Mongolia): focus on the Miocene record. Annalen des Naturhistorischen Museums Wien, 116, 247-269.

Maridet, O., Daxner-Höck, G., Badamgarav, D., \& Göhlich, U. B. (2015). The eomyid rodents (Mammalia) from the Oligocene and Miocene 
of the Valley of Lakes (Central Mongolia). Paläontologische Zeitschrift, 89(2), 207-228.

Maridet, O., Daxner-Höck, G., López-Guerrero, P., \& Göhlich, U.B. (2017). The record of Aplodontidae (Rodentia, Mammalia) from the Oligocene and Miocene of the Valley of Lakes (Central Mongolia) with some comments on the morphologic variability. In G. Daxner-Höck, \& U.B. Göhlich (Eds.) The Valley of Lakes in Mongolia, a key area of Cenozoic mammal evolution and stratigraphy. Palaeobiodiversity and Palaeoenvironments, 97(1). doi: 10.1007/s12549-016-0255-y (this issue).

Morlo, M., \& Nagel, D. (2002). New Didymoconidae (Mammalia) from the Oligocene of Central Mongolia and first information on tooth eruption sequence of the family. Neues Jahrbuch für Geologie und Paläontologie Abhandlungen, 223(1), 123-144.

Morlo, M., \& Nagel, D. (2006). New remains of Hyaenodontidae (Creodonta, Mammalia) from the Oligocene of Central Mongolia. Annales de Paleontologie, 92(3), 305-321.

Morlo, M., \& Nagel, D. (2007). 7. The carnivore guild of the Taatsiin Gol area: Hyaenodontidae (Creodonta, Carnivora and Didymoconidae). In G. Daxner-Höck (Ed), Oligocene-Miocene vertebrates from the Valley of Lakes (Central Mongolia): morphology, phylogenetic and stratigraphic implications. Annalen des Naturhistorischen Museums in Wien, 108A, 217-231.

Nagel, D. \& Morlo, M. (2003). Guild structure of the carnivorous mammals (Creodonta, Carnivora) from the Taatsiin Gol area, Lower Oligocene of Central Mongolia. In J. W. Reumer, \& W. Wessels (Eds), Distribution and Migration of Tertiary Mammals in Europe. Deinsea, 10, 419-429.

Neubauer, T. A., Harzhauser, M., Daxner-Höck, G., \& Piller, W. E. (2013). New data on the terrestrial gastropods from the OligoceneMiocene Transition in the Valley of Lakes, Central Mongolia. Paleontological Journal, 47, 374-385.

Oliver, A., Sanisidro, O., Bayarmaa, B., Ichinnorov, N., \& Daxner-Höck, G. (2017). Turnover and diversification rates in Ctenodactylidae (Rodentia, Mammalia) from Mongolia. In G. Daxner-Höck, \& U.B. Göhlich (Eds.) The Valley of Lakes in Mongolia, a key area of
Cenozoic mammal evolution and stratigraphy. Palaeobiodiversity and Palaeoenvironments, 97(1). doi:10.1007/s12549-016-0256-x.

Richoz, S., Baldermann, A., Frauenwallner, A., Harzhauser, M., DaxnerHöck, G., Klammer, D., Piller, W.E., \& Quezada-Hinoyosa, R. (2017). Geochemistry and mineralogy of Oligocene and early Miocene sediments from the Valley of Lakes, Mongolia. In G. Daxner-Höck, \& U.B. Göhlich (Eds.) The Valley of Lakes in Mongolia, a key area of Cenozoic mammal evolution and stratigraphy. Palaeobiodiversity and Palaeoenvironments, 97(1). doi:10.1007/s12549-016-0268-6.

Schmidt-Kittler, N., Vianey-Liaud, M., \& Marivaux, L. (2007). 6. Ctenodactylidae (Rodentia, Mammalia). In G. Daxner-Höck (Ed), Oligocene-Miocene vertebrates from the Valley of Lakes (Central Mongolia): morphology, phylogenetic and stratigraphic implications. Annalen des Naturhistorischen Museums in Wien, 108A, 173-215.

Stworzewicz, E. (2007). 2. Molluscan fauna (Gastropoda: Pulmonata: Pupilloidea): a systematic review. In G. Daxner-Höck (Ed), Oligocene-Miocene vertebrates from the Valley of Lakes (Central Mongolia): morphology, phylogenetic and stratigraphic implications. Annalen des Naturhistorischen Museums in Wien,108A, 25-41.

Sun, J., \& Windley, B. F. (2015). Onset of aridification by 34 Ma across the Eocene-Oligocene transition in Central Asia. Geology, 11, 10151018. doi:10.1130/G37165.1.

Vislobokova, I. A., \& Daxner-Höck, G. (2002). Oligocene-Early Miocene ruminants from the Valley of Lakes (Central Mongolia). Annalen des Naturhistorischen Museums Wien, 103A, 213-235.

Wessels, W., Badamgarav, D., van Olselen, V., \& Daxner-Höck, G. (2014). Tsaganomyidae (Rodentia, Mammalia) from the Oligocene of Mongolia (Valley of Lakes). Annalen des Naturhistorischen Museums Wien, 116, 293-325.

Ziegler, R., Dahlmann, T., \& Storch, G. (2007). 4. Marsupialia, Erinaceomorpha and Soricomorpha. In G. Daxner-Höck (Ed.), Oligocene-Miocene vertebrates from the Valley of Lakes (Central Mongolia): morphology, phylogenetic and stratigraphic implications. Annalen des Naturhistorischen Museums in Wien, 108A, 53-164. 